\title{
RESEARCH
}

Open Access

\section{The REAL study: a nationwide prospective study of rheumatoid arthritis in Brazil}

\author{
Geraldo da Rocha Castelar-Pinheiro ${ }^{*}$, Ana Beatriz Vargas-Santos ${ }^{2}$, Cleandro Pires de Albuquerque ${ }^{3}$, \\ Manoel Barros Bértolo ${ }^{4}$, Paulo Louzada Júnior ${ }^{5}$, Rina Dalva Neubarth Giorgii, Sebastião Cezar Radominski ${ }^{6}$, \\ Maria Fernanda B. Resende Guimarães ${ }^{8}$, Karina Rossi Bonfiglioli ${ }^{9}$, Maria de Fátima Lobato da Cunha Sauma ${ }^{10}$, \\ Ivânio Alves Pereira ${ }^{11}$, Claiton Viegas Brenol ${ }^{12}$, Evandro Silva Freire Coutinho ${ }^{13}$ and Licia Maria Henrique da Mota ${ }^{3}$
}

\begin{abstract}
Background: There are few data on the epidemiology, clinical manifestations and management of RA in Brazil, even with the recognition of the high direct, indirect and societal costs of this disease. Herein, we report the formation of the REAL - Rheumatoid Arthritis in Real Life, the first nationally representative multicenter prospective observational study in Brazil.
\end{abstract}

Methods: The REAL study was designed to include a total of 1300 evaluable patients from 13 tertiary care public health centers specialized in RA management and representative of 5 regions of Brazil. Each center was expected to enroll $\sim 100$ consecutively seen patients and follow them prospectively in a systematic protocol-driven fashion with scheduled visits at baseline, 6 and 12 months. Core clinical, laboratory and patient-reported outcomes measures were required to be collected at each visit.

Results: A total of 1115 patients (89.4\% female, mean age of 56.7 years and median disease duration of 12.7 years) were enrolled from 11 participating centers. Almost $80 \%$ of patients were of middle-low or low socioeconomic classes. The median educational time was 8 years, with 3.23\% being below literacy level. The interval between symptoms and diagnosis varied from 1 to 457 months (median 12 months). Almost half of the patients were on glucocorticoids, $96.5 \%$ on DMARDs, with $35.7 \%$ on biologics. Median HAQ-DI was 0.875 , ranging from 0 to 3 . Median DAS28-ESR was 3.5, with $58.7 \%$ of patients presenting moderate or high disease activity.

Conclusions: The first large cohort of Brazilian patients with RA in a real-life setting shows several striking differences from previously published cohorts from other countries. The long delay for diagnosis and start of DMARDs may partly explain the high frequency of erosive disease. An elevated percentage of patients on moderate or high disease activity was seen, despite of the high frequency of corticosteroid and biologics utilization. Data from this cohort may enable public health managers of developing countries better allocate the limited resources available for the care of RA patients.

Keywords: Rheumatoid arthritis, Brazilian cohort, Observational study

\footnotetext{
* Correspondence: castelar@uerj.br

${ }^{1}$ Departamento de Medicina Interna, Disciplina de Reumatologia,

Universidade do Estado do Rio de Janeiro, Avenida Nossa Senhora de

Copacabana, 978, sala 508, Copacabana, Rio de Janeiro, RJ 22060-002, Brazil

Full list of author information is available at the end of the article
}

(c) The Author(s). 2018 Open Access This article is distributed under the terms of the Creative Commons Attribution 4.0 International License (http://creativecommons.org/licenses/by/4.0/), which permits unrestricted use, distribution, and reproduction in any medium, provided you give appropriate credit to the original author(s) and the source, provide a link to the Creative Commons license, and indicate if changes were made. The Creative Commons Public Domain Dedication waiver (http://creativecommons.org/publicdomain/zero/1.0/) applies to the data made available in this article, unless otherwise stated. 


\section{Background}

Rheumatoid arthritis (RA) is a systemic, chronic and progressive disease, characterized by synovial inflammation of peripheral joints. Inadequate treatment often results in reduced health-related quality of life and excess mortality [1]. The current concept of RA management relies on early diagnosis, immediate initiation of a disease-modifying antirheumatic drug (DMARD) and effective suppression of inflammation [2]. Advances in diagnostic tools, the availability of new therapeutic options, mainly the biologic agents, and the adoption of a treat-to-target strategy have been of utmost importance for improving patient outcomes [3]. Despite all this progress, in many areas of the world, the diagnosis of RA is delayed and patients remain undertreated, resulting in great negative humanistic and socioeconomic impact $[4,5]$.

Brazil is the largest country in Latin America, with a multiethnic population of around 200 million inhabitants [6]. There are few data on the epidemiology and management of RA in Brazil, even with the recognition of the high direct, indirect and societal costs of this disease [7]. A better understanding of the profile of RA patients seen in public health care centers in Brazil can underpin public health policy, enabling a rational allocation of resources and the setting of priorities in this sector.

The REAL - Rheumatoid Arthritis in Real Life - is a multicenter prospective observational cohort study, with twelve-month follow-up period. The aims of this study were to describe the demographic, clinical and therapeutic features of Brazilian patients with RA, and to evaluate adherence to treatment, safety of pharmacologic treatment, and impact on quality of life, physical function and work capacity of these patients. In this first report of REAL study, we describe the methodology and the baseline characteristics of this cohort.

\section{Methods \\ Setting}

Thirteen tertiary care public healthcare centers (Appendix 1) specialized in RA management were selected to represent the five geographic regions in Brazil. Eventually, 11 centers from 4 regions enrolled in the program. The recruitment period started on August 12th, 2015 and ended on April 15th, 2016. Patients were followed for $\sim 12$ months, with systematic data collection at the initial visit (baseline), at the intermediate visit ( 6 months \pm 1 month) and at the final visit (12 months \pm 1 month), with additional descriptive report of any other unscheduled visit.

\section{Participants}

The inclusion criteria were 1) fulfillment of the 1987 American Rheumatism Association (ARA) or the 2010
American College of Rheumatology (ACR) / European League Against Rheumatism (EULAR) classification criteria for rheumatoid arthritis [8,9]; 2) age 18 years or older; and 3) documented medical record data of at least 6 months of follow up in their healthcare center prior to study enrollment.

Each center was expected to enroll $\sim 100$ patients consecutively. Since all centers were tertiary-care academic rheumatology practices, they were requested to limit the enrollment of biologic-treated patients to roughly the proportion of these patients being treated in their center.

\section{Variables, data sources and data collection}

Table 1 shows the study visit protocol, with all the items systematically evaluated and respective time of assessment. Most data were collected during the medical appointments, with previous medical records used as secondary sources. All data were collected on an electronic medical chart and gathered in a centralized dataset.

\section{Initial visit}

At the initial visit the study physician formally assessed the RA classification criteria fulfillment and collected demographic and contact data, socioeconomic profile, family history of RA, other autoimmune diseases or associated conditions, personal history of comorbidities and lifestyle habits (smoking, alcohol consumption and physical activity). For the socioeconomic classification we used the Brazilian Economic Classification Criterion (BECC), a score system updated in 2015 that includes variables such as the number of household electrical appliances, level of education of the householder and access to public services [10]. The score range is stratified from A to D-E, with each stratum corresponding to an estimated household income (Table 2).

The study physician also assessed the following RA aspects: disease duration, time between symptoms onset and diagnosis, time to first DMARD prescription, health facility and physician specialty at first contact with healthcare due to RA symptoms, presence of extra-articular manifestations, positive rheumatoid factor (RF) and anti-citrullinated protein antibody (ACPA), and presence of bone erosions on radiographic study on both hands and feet. Erosive disease was defined when an erosion (defined as a cortical break) was seen in at least three separate joints at any of the following sites: the proximal interphalangeal, the metacarpophalangeal, the wrist (counted as one joint) and the metatarsophalangeal joints. In addition, prior pharmacologic treatments for RA were described (with respective reasons for discontinuation), history of orthopedic surgery and history of intra-articular or periarticular steroid injections. 
Table 1 Variables assessed in study visits

\begin{tabular}{|c|c|c|c|c|}
\hline \multirow[t]{2}{*}{ Variables } & & \multirow[t]{2}{*}{$\begin{array}{l}\text { Initial } \\
\text { visit }\end{array}$} & \multirow{2}{*}{$\begin{array}{l}\text { Intermediate } \\
\text { visit } \\
\text { ( } 6 \pm 1 \text { months) }\end{array}$} & \multirow{2}{*}{$\begin{array}{l}\text { Final visit } \\
\text { (12 } \pm 1 \text { months) }\end{array}$} \\
\hline & & & & \\
\hline \multirow[t]{2}{*}{ Study entry } & Invitation & $x$ & & \\
\hline & Informed consent & $x$ & & \\
\hline \multirow{16}{*}{$\begin{array}{l}\text { Medical history with chart } \\
\text { review }\end{array}$} & Evaluation of inclusion and exclusion criteria & $x$ & & \\
\hline & Demographic data & $x$ & & \\
\hline & Socioeconomic data & $x$ & & \\
\hline & Disease duration & $x$ & & \\
\hline & Time from symptoms onset to diagnosis & $x$ & & \\
\hline & Time from symptoms onset to the 1st DMARD & $x$ & & \\
\hline & $\begin{array}{l}\text { Local and medical specialty of the physician on the 1st appointment } \\
\text { related with the onset of symptoms }\end{array}$ & $x$ & & \\
\hline & Previous medications/ injections & $x$ & & \\
\hline & History of joint surgeries & $x$ & & $x$ \\
\hline & Comorbidities & $x$ & & $x$ \\
\hline & Extra-articular manifestations & $x$ & & $x$ \\
\hline & Alcohol consumption & $x$ & & $x$ \\
\hline & Smoking & $x$ & & $x$ \\
\hline & Physical exercise frequency & $x$ & & $x$ \\
\hline & Employment situation & $x$ & $x$ & $x$ \\
\hline & Medications in use/injections & $x$ & $x$ & $x$ \\
\hline \multirow[t]{4}{*}{ Physical Exam } & Blood pressure & $x$ & $x$ & $x$ \\
\hline & Heart rate & $x$ & $x$ & $x$ \\
\hline & Body mass index & $x$ & $x$ & $x$ \\
\hline & Joint count & $x$ & $x$ & $x$ \\
\hline \multirow[t]{10}{*}{ Patient reported outcomes } & Functional capacity (HAQ-DI) & $x$ & $x$ & $x$ \\
\hline & Pain (VAS) & $x$ & $x$ & $x$ \\
\hline & General health (VAS) & $x$ & $x$ & $x$ \\
\hline & Disease activity within in the previous 6 months VAS & $x$ & $x$ & $x$ \\
\hline & Current disease activity VAS & $x$ & $x$ & $x$ \\
\hline & Fatigue (VAS) & $x$ & $x$ & $x$ \\
\hline & Morning stiffness (VAS) & $x$ & $x$ & $x$ \\
\hline & Quality of life (SF-12 / SF-6D) & $x$ & $x$ & $x$ \\
\hline & DMARD use and adherence & $x$ & $x$ & $x$ \\
\hline & Articular index assessment & $x$ & $x$ & $x$ \\
\hline \multirow[t]{4}{*}{ Laboratory } & Erythrocyte sedimentation rate $(\mathrm{mm})$ & $x$ & $x$ & $x$ \\
\hline & C-reactive protein (mg/dL) & $x$ & $x$ & $x$ \\
\hline & Rheumatoid factor & $x$ & & \\
\hline & Anti-citrullinated protein antibody & $x$ & & \\
\hline X-ray & Bone erosions of hands and feet & $x$ & & \\
\hline Physician assessment & Assessment of disease activity by a rheumatologist & $x$ & $x$ & $x$ \\
\hline \multirow[t]{4}{*}{ Disease activity index } & DAS28-ESR & $x$ & $x$ & $x$ \\
\hline & DAS28-CRP & $x$ & $x$ & $x$ \\
\hline & CDAl & $x$ & $x$ & $x$ \\
\hline & SDAI & $x$ & $x$ & $x$ \\
\hline
\end{tabular}


Table 1 Variables assessed in study visits (Continued)

\begin{tabular}{cccc}
\hline Variables & $\begin{array}{l}\text { Initial } \\
\text { visit }\end{array}$ & $\begin{array}{l}\text { Intermediate } \\
\text { visit } \\
(6 \pm 1 \text { months })\end{array}$ & $\begin{array}{c}\text { Final visit } \\
(12 \pm 1 \text { months })\end{array}$ \\
\hline RADAI & $\times$ & $\times \quad \times$ & $\times$
\end{tabular}

DMARD disease-modifying antirheumatic drug, HAQ-DI Health Assessment Questionnaire-Disability Index, VAS visual analogue scale, SF-12 12-Item Short-Form Health Survey, SF-6D Short-Form 6 dimensions, DAS28 Disease Activity Score 28-joint count, CDAI Clinical Disease Activity Index, SDAI Simplified Disease Activity Index, RADAl Rheumatoid Arthritis Disease Activity Index

Clinical evaluation included vital signs, anthropometric measures, tender and swollen joint counts, and physician score on the visual analogue scale (VAS) of disease activity. Patient reported outcomes included pain (VAS), global health (VAS), current and previous 6 months disease activity (VAS), fatigue (VAS), morning stiffness (VAS) and articular index, in which the patient evaluates the presence of pain and respective intensity in 16 joints. All laboratory tests, including erythrocyte sedimentation rate (ESR) and C-reactive protein (CRP) were recorded. Compliance to prescribed medications as well as scheduled medical appointments and laboratory tests were also recorded.

The disease activity score-28 joints (DAS28), clinical disease activity index (CDAI), simplified disease activity index (SDAI) and the rheumatoid arthritis disease activity index (RADAI) were also calculated for each appointment [11-13].

The translated and validated versions of the Health Assessment Questionnaire-Disability Index (HAQ-DI), Short Form-12 (SF-12) and SF-6D evaluated, respectively, physical function, functional capacity and wellbeing, and health status from the patient's perspective [14-16].

In this report, we summarize important demographic and clinical data at the baseline visit of all enrolled patients.

\section{Intermediate and final visits}

At the intermediate and the final visits, some variables from the medical history, such as change in the marital and employment status, onset of new extra-articular manifestations or comorbidities and medical intercurrences were reassessed. All the items within the physical

Table 2 Brazilian Economic Classification Criterion (BECC): relation between socioeconomic strata and estimated household income

\begin{tabular}{ll}
\hline Socioeconomic Strata & Household income (US dollar ${ }^{\mathrm{a}}$ ) \\
\hline A & 5921.00 \\
B1 & 2623.00 \\
B2 & 1357.00 \\
C1 & 766.81 \\
C2 & 460.65 \\
D-E & 217.71 \\
\hline
\end{tabular}

${ }^{a}$ Conversion of Brazilian reais into US dollars made in accordance with the exchange rate of April 16, 2016- US\$1,00: $R \$ 3,5276$ exam domain, the patient reported outcomes, the lab tests ESR and CRP along with the disease activity indexes, were evaluated at the three scheduled visits (Table 1). Additionally, at the final visit, physicians were requested to describe their therapeutic plan.

\section{Ethical aspects}

This study was approved by the National Commission of Ethics in Research (CONEP - Comissão Nacional de Ética em Pesquisa) - Ministry of Health. The coordinating center was the Rio de Janeiro State University, and the approval number was 45781015.8.1001.5259. Each of the centers also obtained approval from the respective Institutional Review Boards. All patients signed the informed consent form.

\section{Results}

A total of 1115 patients were enrolled in the study. The general demographic and clinical data of the population at the time of the initial evaluation are presented in Tables 3 and 4. Approximately 90\% were female, with a mean age of 56.7 years and median disease duration of 12.7 years. The majority of subjects were white, with minorities from Asian and Brazilian-Indian origins making up $1 \%$ of the sample. Almost $80 \%$ of patients were classified as pertaining to middle-low or low socioeconomic classes. Median BMI was $27 \mathrm{~kg} / \mathrm{m}^{2}$, with $64 \%$ of the patients classified as overweight or obese. The median educational time was 8 years, with $3.23 \%$ being below literacy level. About $40 \%$ were either current or former smokers.

The interval between symptoms and diagnosis varied from 1 to 457 months (median 12 months). The gap between symptoms onset and first DMARD initiation was wider, ranging from 1 to 624 months, but the same median value of 12 months.

The seropositivity rate was similar between RF (78\%) and ACPA (77\%), but it is important to highlight that the latter was assessed in less than half of the patients.

Interestingly, similar numbers of patients fulfilled the ARA 1987 and the 2010 ACR-EULAR classification criteria for RA, with $80.8 \%$ of subjects meeting both criteria. All patients met at least one criteria. 
Table 3 Baseline demographic data of patients enrolled in the REAL study

\begin{tabular}{|c|c|c|}
\hline Demographic data & Absolute value or \% & $\mathrm{N}$ \\
\hline Age, years, median (range) & $56.7(22.1-88.8)$ & 1115 \\
\hline Female gender, \% & 89.4 & 1115 \\
\hline Ethnicity/race/color, \% & & 1115 \\
\hline White & 56.8 & \\
\hline Pardo $^{a}$ & 31.3 & \\
\hline Black & 10.9 & \\
\hline Others & 1.0 & \\
\hline Smoking, \% & & 1115 \\
\hline Smoker & 10.9 & \\
\hline Former smoker & 28.6 & \\
\hline Never smoked & 60.5 & \\
\hline BMI categories, \% & & 1046 \\
\hline Low weight & 5.0 & \\
\hline Normal & 31.5 & \\
\hline Overweight & 35.3 & \\
\hline Obesity & 28.2 & \\
\hline Total formal education time, years, median (range) & $8(0-20)$ & 1075 \\
\hline $\begin{array}{l}\text { Brazilian Economic Classification Criterion: Socioeconomic Strata: Gross family income } \\
\text { in the month in US dollar }{ }^{\circ}, \%\end{array}$ & & 1101 \\
\hline$A(5,921.00)$ & 1.4 & \\
\hline B1 (2623.00) & 3.5 & \\
\hline B2 (1357.00) & 18.4 & \\
\hline C1 (766.81) & 27.4 & \\
\hline C2 (460.65) & 31.3 & \\
\hline D-E (217.71) & 18.0 & \\
\hline
\end{tabular}

${ }^{\mathrm{a}}$ Mixed white and black ethnicities. BMI Body mass index. ${ }^{\mathrm{b}}$ Conversion of Brazilian reais into US dollars made in accordance with the exchange rate of April 16 , 2016 - US\$1,00: R\$3,5276

Almost half of the patients were on glucocorticoids, $96.5 \%$ on DMARDs, with $35.7 \%$ on biologics. Of those on biologics $(n=398), 15.6 \%$ were on monotherapy.

Median HAQ-DI was 0.875 , ranging from 0 to 3 . Median DAS28-ESR was 3.5, with $58.7 \%$ of patients presenting moderate or high disease activity. When assessed by CDAI, the median score represented low disease activity (CDAI $=9$ ), with $46.7 \%$ of subjects classified as presenting moderate to high disease activity.

\section{Discussion}

We describe the formation of the first large cohort of Brazilian patients with RA in a real-life setting, with consecutive enrollment of subjects and systematic data collection. The demographic, clinical, serological and radiographic characteristics of the patients being followed have several similar but some divergent characteristics from previously published North American, European and Latin American cohorts [17-21]. Particularly notable are the long delay for diagnosis, the high frequency of corticosteroid use and of erosive disease, as well as, the elevated percentage of patients on moderate or high disease activity. The high frequency of biologic DMARD use, considering the economic limitations in Brazil, is also remarkable. The fact that most patients were either RF or ACPA positive and had a delay in the initiation of DMARD may explain the observed high frequency (almost 60\%) of moderate or high disease activity and erosive disease. The ethnic and socioeconomic class distribution reflects the Brazilian population in general, and is considerably different from other international cohorts [17-22]. It is important to note that the socioeconomic class distribution likely reflects the patients seen at the participating centers, which provide free health care within the Brazilian Public Health System -Sistema Único de Saúde (SUS). In Brazil, three quarters of the population is served by this public and free system, with the others using various private and paid health plans [23] and the latter were likely not represented to a significant degree in this study. About $11 \%$ of REAL patients were currently smokers, a number lower than 
Table 4 Baseline clinical data of patients enrolled in the REAL study

\begin{tabular}{|c|c|c|}
\hline Clinical Data & Absolute value or \% & $n$ \\
\hline Disease duration, years, median (range) & $12.7(0.7-56.9)$ & 1114 \\
\hline Time from symptoms to diagnosis, months, median (range) & $12(1-457)$ & 1078 \\
\hline Time from symptoms to 1st DMARD, months, median (range) & $12(1-624)$ & 994 \\
\hline Patients with $\geq 1$ extra-articular manifestation, $\%$ & 23.3 & 1115 \\
\hline Positive rheumatoid factor, \% & 78.2 & 1105 \\
\hline Positive anti-citrullinated peptide antibody, $\%$ & 77.2 & 477 \\
\hline Erosive disease, \% & 54.9 & 1095 \\
\hline \multicolumn{3}{|l|}{ Patients fulfilling classification criteria, \%: } \\
\hline ARA 1987 & 90.0 & 1115 \\
\hline ACR/EULAR 2010 & 90.9 & 1115 \\
\hline Both & 80.8 & 1115 \\
\hline \multicolumn{3}{|l|}{ Drugs in use, \%: } \\
\hline Glucocorticoids & 47.4 & 1115 \\
\hline Nonsteroidal anti-inflammatory drugs & 9.1 & 1115 \\
\hline Synthetic DMARD & 90.9 & 1115 \\
\hline Methotrexate & 66.5 & 1115 \\
\hline Biologic DMARD & 35.7 & 1115 \\
\hline Biologic DMARD in monotherapy & 5,6 & 1115 \\
\hline ESR, median (range) & $21(1-140)$ & 923 \\
\hline CRP median (range) & $0.7(0-76.1)$ & 944 \\
\hline Pain (VAS 0-100), median (range) & $40(0-100)$ & 1115 \\
\hline Fatigue (VAS 0-100), median (range) & $40(0-100)$ & 1115 \\
\hline Global health assessment (VAS 0-100), median (range) & $38(0-100)$ & 1115 \\
\hline DAS28-ESR, median (range) & $3.5(0.3-8.2)$ & 923 \\
\hline Remission & 26.2 & \\
\hline Low disease activity & 15.1 & \\
\hline Moderate disease activity & 41.8 & \\
\hline High disease activity & 16.9 & \\
\hline CDAl, median (range) & $9(0-70)$ & 1113 \\
\hline Remission & 20.1 & \\
\hline Low disease activity & 33.2 & \\
\hline Moderate disease activity & 27.5 & \\
\hline High disease activity & 19.2 & \\
\hline HAQ-DI, median (range) & $0.875(0-3)$ & 1111 \\
\hline SF-12 physical, median (range) & $36.1(17.5-55.9)$ & 1079 \\
\hline SF-12 mental, median (range) & $47.1(14.3-72.0)$ & 1079 \\
\hline
\end{tabular}

ARA American Rheumatism Association, ACR American College of Rheumatology, EULAR European League Against Rheumatism, DMARD disease-modifying antirheumatic drug, VAS visual analogue scale, ESR erythrocyte sedimentation rate ( $\mathrm{mm} /$ first hour), CRP C-reactive protein (mg/dL), DAS28 Disease Activity Score 28-joint count, CDAl: Clinical Disease Activity Index, HAQ Health Assessment Questionnaire-Disability Index, SF-12 12-Item Short-Form Health Survey

that published in previous RA studies from other parts of the world (25-33\%), but consistent with the relatively low rates of smoking in the Brazilian population (females: 8.2\% and males: $12.6 \%$ ) [24-27]. Subsequent publications will explore the relationship of these differences with clinical and outcome variables.
We recognize several limitations of the REAL study. All the sites enrolled in the study are "reference centers", and thus are unlikely to represent the broader management of RA across the country. It is probable that these patients present more severe disease, with a less favorable prognosis. REAL study was designed to be 
representative of the entire Brazilian population, but one center in the Northeast (representing 27.9\% of population) could not participate because of delays in the Ethics Committee approval. Also, our cohort does not include patients from among the $25 \%$ of Brazilian population receiving their healthcare outside of the public health system. On the other hand, the REAL study data reflects perhaps a more optimal standard of care possibly resulting in better outcomes in comparison with those treated in less prepared facilities. Further publications will study multiple management strategies and their effects on patient outcomes.

\section{Conclusions}

The first large cohort of Brazilian patients with RA in a real-life setting shows several striking differences from previously published cohorts from other countries. The long delay for diagnosis and start of DMARDs may partly explain the high frequency erosive disease. An elevated percentage of patients on moderate or high disease activity was seen, despite of the high frequency of corticosteroid and biologics utilization. Data from this cohort may enable public health managers of developing countries better allocate the limited resources available for the care of RA patients.

\section{Appendix 1}

Table 5 Thirteen tertiary care public healthcare centers specialized in RA management representing the five geographic regions in Brazil

\begin{tabular}{lll}
\hline Centers & $\begin{array}{l}\text { Number of } \\
\text { patients included }\end{array}$ & $\begin{array}{l}\text { Geographic } \\
\text { region }\end{array}$ \\
\hline Universidade Estadual de Campinas & 111 & Southeast \\
Universidade de Brasília & 107 & Midwest \\
Universidade Federal do Pará & 102 & North \\
Universidade do Estado do Rio de & 100 & Southeast \\
Janeiro & & South \\
Universidade Federal do Paraná & 100 & South \\
$\begin{array}{l}\text { Universidade Federal do Rio Grande } \\
\text { do Sul }\end{array}$ & 102 & South \\
$\begin{array}{l}\text { Universidade Federal de Santa } \\
\text { Catarina }\end{array}$ & 100 & Southeast \\
$\begin{array}{l}\text { Universidade de São Paulo - Ribeirão } \\
\text { Preto }\end{array}$ & 99 & Southeast \\
Universidade Federal de Minas Gerais & 99 & Southeast \\
Hospital do Servidor Público Estadual & 99 & Southeast \\
de São Paulo & & 0
\end{tabular}

\section{Acknowledgements}

Gurkirpal Singh, MD and Leticia Rocha provided technical and writing assistance.

\section{Funding}

This work was supported by the Brazilian Society of Rheumatology (BSR). For this project, BSR received specific grant support from the following companies: Bristol-Myers Squibb Farmacêutica Ltda; Eli Lilly do Brasil Ltda; Janssen-Cilag Farmacêuticos Ltda; Laboratórios Pfizer Ltda; Produtos Roche Químicos e Farmacêuticos S.A. and UCB Biopharma Ltda. The funding body or the companies had no role in the design of the study and collection, analysis, and interpretation of data and in writing the manuscript.

\section{Authors' contributions}

All authors made substantial contributions to the acquisition of data, have been involved in drafting the manuscript or revising it critically for important intellectual content, gave final approval of the version to be published and have participated sufficiently in the work to take public responsibility for appropriate portions of the content; and agreed to be accountable for all aspects of the work in ensuring that questions related to the accuracy or integrity of any part of the work are appropriately investigated and resolved. In addition, GRCP, ABVS and LMHM also made substantial contributions to conception and design of the study.

\section{Ethics approval and consent to participate}

This study was approved by the National Commission of Ethics in Research (CONEP - Comissão Nacional de Ética em Pesquisa) - Ministry of Health. The coordinating center was the University of the State of Rio de Janeiro, and the approval number was 45781015.8.1001.5259. Each of the centers also obtained approval from the respective Institutional Review Boards. All patients signed the informed consent form.

\section{Competing interests}

GRCP: Has received consulting fees from AbbVie, Bristol-Myers Squibb, Eli Lilly, Glaxosmithkline, Janssen, Pfizer, Sanofi Genzyme and Roche; ABVS: Has received supporting for international medical events from AbbVie and Janssen; CPA: Has received personal fees and/or non-financial support from Pfizer, AbbVie, AstraZeneca, Janssen, Bristol-Myers Squibb, Roche, Novartis and UCB, outside the submitted work; MBB: Has participated in clinical and/or experimental studies related to this work and sponsored by Roche; has delivered speeches at events related to this work and sponsored by AbbVie and Pfizer; PL: Has received supporting for internationals congresses from BristolMyers Squibb, UCB and consulting fees from Pfizer; RDNG: Has received consulting fees, speaking fees and supporting for internationals congresses from Roche, Pfizer, Bristol-Myers Squibb, UCB, Eli-Lilly, AbbVie, Abbott and EMS; SCR: Has received consulting and speaking fees from Abbvie, Janssen, Pfizer, Roche and UCB; MFBRG: Has received speaking fees and supporting for congresses from AbbVie, Bristol-Myers Squibb, Janssen, Novartis, Pfizer, Roche and UCB; KRB: Has received speaking fees and supporting for international congresses from Roche, Pfizer, Bristol-Myers Squibb, Abbvie and Janssen; MFLCS: No financial disclosures; CVB: Has participated in clinical and/or experimental studies related to this work and sponsored by AbbVie, BMS, Janssen, Pfizer and Roche; has received personal or institutional support from AbbVie, BMS, Janssen, Pfizer and Roche; has delivered speeches at events related to this work and sponsored by AbbVie, Janssen, Pfizer and Roche; IAP: Has received consulting fees, speaking fees and supporting for internationals congresses from Roche, Pfizer, UCB Pharma, Eli-Lilly, Abbvie and Janssen; ESFC: No financial disclosures; LMHM: Has received personal or institutional support from AbbVie, Janssen, Pfizer and Roche; has delivered speeches at events related to this work and sponsored by AbbVie, Janssen, Pfizer, Roche and UCB.

\section{Publisher's Note}

Springer Nature remains neutral with regard to jurisdictional claims in published maps and institutional affiliations.

\section{Author details \\ 'Departamento de Medicina Interna, Disciplina de Reumatologia, Universidade do Estado do Rio de Janeiro, Avenida Nossa Senhora de Copacabana, 978, sala 508, Copacabana, Rio de Janeiro, RJ 22060-002, Brazil. ${ }^{2}$ Serviço de Reumatologia, Hospital Universitário Pedro Ernesto -}


Universidade do Estado do Rio de Janeiro, Rio de Janeiro, Brazil. ${ }^{3}$ Serviço de Reumatologia, Hospital Universitário de Brasília - Universidade de Brasília, Brasília, Brazil. ${ }^{4}$ Disciplina de Reumatologia, Faculdade de Ciências Médicas, Universidade Estadual de Campinas, Campinas, Brazil. ${ }^{5}$ Disciplina de Reumatologia, Faculdade de Medicina da Universidade de Ribeirao Preto, Universidade de Sao Paulo, Ribeirão Preto, Brazil. 'Serviço de Reumatologia, Instituto de Assistência Médica ao Servidor Público Estadual, Hospital do Servidor Público Estadual de São Paulo, São Paulo, Brazil. "isciplina de Reumatologia, Faculdade de Medicina da Universidade Federal do Paraná, Universidade Federal do Paraná, Curitiba, Brazil. ${ }^{8}$ Serviço de Reumatologia, Hospital das Clínicas, Universidade Federal de Minas Gerais, Belo Horizonte, Brazil. ${ }^{9}$ Disciplina de Reumatologia, Faculdade de Medicina, Universidade de São Paulo, São Paulo, Brazil. ${ }^{10}$ Disciplina de Reumatologia, Faculdade de Medicina, Universidade Federal do Pará, Belém, Brazil. "'Serviço de Reumatologia, Hospital Universitário, Universidade Federal de Santa Catarina, Florianópolis, Brazil. ${ }^{12}$ Serviço de Reumatologia, Departamento de Medicina Interna, Universidade Federal do Rio Grande do Sul, Porto Alegre, Brazil. ${ }^{13}$ Departamento de Epidemiologia e Métodos Quantitativos em Saúde, Fundação Osvaldo Cruz, Rio de Janeiro, Brazil.

Received: 5 March 2018 Accepted: 15 June 2018

Published online: 28 June 2018

\section{References}

1. van der Linden MP, Knevel R, Huizinga TW, et al. Classification of rheumatoid arthritis: comparison of the 1987 American College of Rheumatology criteria and the 2010 American College of Rheumatology/ European league against rheumatism criteria. Arthritis Rheum. 2011;63:37-42.

2. Singh JA, Saag KG, Bridges SL Jr, et al. 2015 American College of Rheumatology Guideline for the treatment of rheumatoid arthritis. Arthritis Rheumatol. 2016;68:1-26.

3. Smolen JS, Aletaha D, Barton A, et al. Rheumatoid arthritis. Nat Rev Dis Primers. 2018:4:18001.

4. Sokka T, Kautiainen $\mathrm{H}$, Pincus T, et al. Disparities in rheumatoid arthritis disease activity according to gross domestic product in 25 countries in the QUEST-RA database. Ann Rheum Dis. 2009;68:1666-72.

5. Burgos Vargas $\mathrm{R}$, Cardiel MH. Rheumatoid arthritis in Latin America. Important challenges to be solved Clin Rheumatol. 2015;34(Suppl 1):S1-3.

6. "World Population Prospects: The 2017 Revision" ESA.UN.org (custom data acquired via website). United Nations Department of Economic and Social Affairs, Population Division. https://www.un.org/development/desa/ publications/world-population-prospects-the-2017-revision.html. Accessed 10 Feb 2018.

7. Azevedo $\mathrm{AB}$, Ferraz MB, Ciconelli RM. Indirect costs of rheumatoid arthritis in Brazil. Value Health. 2008;11:869-77.

8. Arnett FC, Edworthy SM, Bloch DA, et al. The American rheumatism association 1987 revised criteria for the classification of rheumatoid arthritis. Arthritis Rheum. 1988:31:315-24.

9. Aletaha D, Neogi T, Silman AJ, et al. 2010 rheumatoid arthritis classification criteria: an American College of Rheumatology/European league against rheumatism collaborative initiative. Ann Rheum Dis. 2010;69:1580-8.

10. ABEP. Brazilian Criteria 2015 and social class distribution update for 2016 , ABEP - Associação Brasileira de Empresas de Pesquisa/Brazilian Market Research Association - 2016 - http://www.abep.org/criterio-brasil Accessed 10 Feb 2018

11. van der Heidjde DMFM, van't Hof MA, PLCM v R, de Putte LBA v. Development of a disease activity score based on judgment in clinical practice by rheumatologists. J Rheumatol. 1993;20:579-81.

12. Aletaha $\mathrm{D}$, Smolen J. The simplified disease activity index (SDAI) and the clinical disease activity index (CDAl): a review of their usefulness and validity in rheumatoid arthritis. Clin Exp Rheumatol. 2005;23(Suppl 39):S100-8.

13. Stucki G, Liang MH, Stucki S, et al. A self-administered rheumatoid arthritis disease activity index (RADAl) for epidemiologic research. Psychometric properties and correlation with parameters of disease activity. Arthritis Rheum. 1995;38:795-8.

14. Ferraz MB, Oliveira LM, Araujo PM, et al. Crosscultural reliability of the physical ability dimension of the health assessment questionnaire. J Rheumatol. 1990;17:813-7.

15. Silveira MF, Almeida JC, Freire RS, et al. Psychometric properties of the quality of life assessment instrument: 12-item health survey (SF-12). Cien Saude Colect. 2013;18:1923-31.
16. Campolina AG, Bortoluzzo AB, Ferraz MB, et al. Validation of the Brazilian version of the generic six-dimensional short form quality of life questionnaire (SF-6D Brazil). Cien Saude Colet. 2011;16:3103-10.

17. Curtis JR, Jain A, Askling J, et al. A comparison of patient characteristics and outcomes in selected European and U.S. rheumatoid arthritis registries. Semin Arthritis Rheum. 2010;40:2-14.

18. Sokka T, Toloza S, Cutolo M, et al. Women, men, and rheumatoid arthritis: analyses of disease activity, disease characteristics, and treatments in the QUEST-RA study. Arthritis Res Ther. 2009;11:R7.

19. van der Zee-Neuen A, Putrik P, Ramiro S, et al. Large country differences in work outcomes in patients with RA - an analysis in the multinational study COMORA. Arthritis Res Ther. 2017;19:216.

20. Estel BAP, Massardo L, Wojdyla D, et al. Is there something we can learn from rheumatoid arthritis in Latin America? A descriptive report on an inception cohort of 1093 patients [abstract]. Ann Rheum Dis. 2008;67:336.

21. Cardiel MH, Pons-Estel BA, Sacnun MP, et al. Treatment of early rheumatoid arthritis in a multinational inception cohort of Latin American patients: the GLADAR experience. J Clin Rheumatol. 2012;18:327-35.

22. https://ww2.ibge.gov.br/english/estatistica/populacao/caracteristicas_raciais/ default_raciais.shtm. Accessed 10 Feb 2018.

23. Lewis $M$, Penteado $E$, Malik AM. Brazil's mixed public and private hospital system. World Hosp Health Serv. 2015;51:22-6.

24. Balsa A, Lojo-Oliveira L, Alperi-López M, et al. Prevalence of Comorbidities in Rheumatoid Arthritis and Evaluation of Their Monitoring in Clinical Practice: The Spanish Cohort of the COMORA Study. Reumatol Clin. 2017. https://doi. org/10.1016/.jreuma.2017.06.002. [Epub ahead of print]

25. Meissner $Y$, Richter A, Manger B, et al. Serious adverse events and the risk of stroke in patients with rheumatoid arthritis: results from the German RABBIT cohort. Ann Rheum Dis. 2017;76:1583-90.

26. GBD 2015 Tobacco Collaborators. Smoking prevalence and attributable disease burden in 195 countries and territories, 1990-2015: a systematic analysis from the Global Burden of Disease Study 2015. Lancet. 2017;389: 1885-906.

27. Lotufo PA. Smoking control in Brazil: a public health success story. Sao Paulo Med J. 2017:135:203-4.

\section{Ready to submit your research? Choose BMC and benefit from:}

- fast, convenient online submission

- thorough peer review by experienced researchers in your field

- rapid publication on acceptance

- support for research data, including large and complex data types

- gold Open Access which fosters wider collaboration and increased citations

- maximum visibility for your research: over $100 \mathrm{M}$ website views per year

At BMC, research is always in progress.

Learn more biomedcentral.com/submissions 